\title{
Effect of Various Cultural Practices on Yields of Yams in Puerto Rico ${ }^{1}$
}

\author{
Rubén Caro Costas, Elvin Boneta, and Servando Silva
}

\section{INTRODUCTION}

Yams (Dioscorea sp.) are a major food crop of the Humid Tropics, yet there is limited information on their cultural requirements under varying soil and climatic conditions. Wood (6), ${ }^{3}$ Campbell and Gooding (1), and Chapman (2) found that staking increased yields of yams and Chapman (2) found that 6-foot stakes resulted in higher yields than 3-foot stakes. Kinman (4) found that yields of yams were related to vine growth.

Wood $(6)$ found that higher yields were produced at 4-foot $x$ 1-foot than at 4-foot $x$ 2-foot planting distance. Vicente-Chandler et al. (5) found that just as high yields of yams were produced in undisturbed as in thoroughly tilled soils of Puerto Rico's Mountain Region. Kasasian (8) obtained good results with Simazine ${ }^{4}$ and Diuron ${ }^{4}$ or Atrazine ${ }^{4}$ in combination with TCA as herbicides for yams.

This paper presents results of studies to determine the effect of plant population, planting system, staking, planting in beds, and applications of Simazine herbicide on yields of yams, under typical conditions in the Mountain Region of Puerto Rico.

\section{MATERIALS AND PROCEDURE}

Except as noted, the procedure described below was used in all three experiments summarized in this paper.

The Guinea Blanco variety used in all experiments was planted in the spring and the crop was harvested in late winter after the vines dried up. Plots were weeded as required.

All plots received 200 pounds of nitrogen as ammonium sulfate, 62 pounds

1 This paper covers work carried out cooperatively between the Soil and Water Conservation Research Division, Agricultural Research Service, USDA, and the Agricultural Experiment Station, Mayagüez Campus, University of Puerto Rico, Río Piedras, P.R.

${ }^{2}$ Agronomist, cooperative between the Agricultural Experiment Station of the University of Puerto Rico and the Soil and Water Conservation Research Division, USDA, Research Assistant at the Agricultural Experiment Station, Mayagüez Campus, University of Puerto Rico, stationed at Adjuntas, and Agricultural Technician, Soil and Water Conservation Research Division, Agricultural Research Service, USDA, respectively, stationed at Río Piedras, P.R.

Italic numbers in parentheses refer to Literature Cited, p. 361.

- Trade names are used to provide specific information; this does not imply endorsement or recommendation. 
of phosphorus ( 150 pounds $\mathrm{P}_{2} \mathrm{O}_{5}$ ) as triple superphosphate, and 400 pounds of potassium as potassium chloride per acre in two equal applications, approximately 1 and 4 months after planting. The soil was limed to $\mathrm{pH} 5.5$ where required.

\section{Experiment A (1965)}

The objective of experiment $A$ was to determine the effect of plant population, planting system, staking, and planting in beds, on yields of yams.

Treatments shown in table 1 were replicated three times in a split-plot

TABLD 1.-Effect of plant population, planting system, staking, and planting in beds on yields of the Guinea blanco variety of yams growing on Humata clay at Orocovis

\begin{tabular}{|c|c|c|c|c|c|}
\hline \multirow{2}{*}{$\begin{array}{l}\text { Treatment } \\
\text { No. }\end{array}$} & \multirow{2}{*}{ Planting1 distance } & \multirow{2}{*}{$\begin{array}{c}\text { Plants } \\
\text { per acre }\end{array}$} & \multicolumn{2}{|c|}{ Yields per acre ${ }^{2}$} & \multirow{2}{*}{$\begin{array}{l}\text { Increase } \\
\text { in yields } \\
\text { duc to } \\
\text { staking }\end{array}$} \\
\hline & & & Unstaked & Staked & \\
\hline $\begin{array}{l}1 \\
2 \\
3 \\
4\end{array}$ & $\begin{array}{l}4 \text { feet } \times 21 / 2 \text { feet } \\
4 \text { feet } \times 11 / 2 \text { feet } \\
4 \text { feet } \times 1 \text { feet } \\
4 \text { feet } \times 11 / 2 \text { feet in } \\
\text { beds } 10 \text { inches } \\
\text { high }\end{array}$ & $\begin{array}{r}4,356 \\
7,260 \\
10,890 \\
7,260\end{array}$ & $\begin{array}{c}\text { Cwt. } \\
119 \text { b }(2.6) \\
225 \text { a }(2.8) \\
236 \text { a }(2.1) \\
216 \text { a }(2.3)\end{array}$ & $\begin{array}{c}\text { Cwot. } \\
214 \text { c }(4.7) \\
303 \text { b }(4.2) \\
310 \text { b }(3.2) \\
392 \text { a }(4.7)\end{array}$ & $\begin{array}{r}\text { Crot. } \\
95 \\
78 \\
74 \\
176\end{array}$ \\
\hline & S.D. ${ }^{05}$ for staking & & & & \\
\hline
\end{tabular}

1 Flat plantings except as indicated.

Yields having 1 or more letters in common do not differ significantly; numbers in parentheses show average weight of individual tubers in pounds.

design with staking as the main plots, and population, planting system, and planting in beds as the subplots. Individual plots were 12 feet $\times 20$ feet.

The experiment was carried out on Cialitos (Humata) clay, near Orocovis. The soil contained 4.8-percent organic matter, had a $\mathrm{pH}$ of 5.0, and an exchange capacity of 14.5 meq. with 4.6 meq. of exchangeable bases per $100 \mathrm{~g}$. of soil. The soil had a bulk density of 1.0 .

\section{Experiment B (1966)}

The objective of experiment $B$ was to determine the effect of plant population and planting system on yields of yams planted in raised beds approximately 10 inches high and supported by stakes.

Treatments shown in table 2 were replicated five times in a randomized 
block design. Individual plots were 12 feet $\mathrm{x} 12$ feet. The yams were planted in beds and were supported by 6 -foot stakes.

The experiment was carried out on a Limani silty clay loam near Adjuntas. The soil contained 5.6-percent organic matter, had a $\mathrm{pH}$ of 6.3, and an exchange capacity of 15.0 meq., with 12.4 meq. of exchangeable bases per $100 \mathrm{~g}$. of soil.

\section{Experiment $C$}

The objective of experiment $\mathbf{C}$ was to compare Simazine applications with hand cultivation on weed control and yields of yams.

Treatments, replicated five times in a randomized block design, were as follows: 1, Hand-weeded 3 times; 2,8 pounds Simazine applied per acre in 1

TABLE 2.-Effect of population and planting system on yields of the Guinea Blanco variety of yams, supported by stakes and planted in beds in a Limani soil at Adjuntas

\begin{tabular}{c|c|c|c}
\hline Treatment No. & Planting distance & Plants per acre & Vields per acre \\
1 & Feet & Number & Cwt. \\
2 & 4 feet $\times 21 / 2$ feet & 4,356 & $364 \mathrm{e}$ \\
3 & 4 feet $\times 11 / 2$ feet & 7,260 & $388 \mathrm{~d}$ \\
4 & 4 feet $\times 1$ feet & 10,890 & $453 \mathrm{c}$ \\
5 & 3 feet $\times 2$ feet & 7,260 & $476 \mathrm{~b}$ \\
\hline \hline & 2 feet $\times 2$ feet & 10,890 & $537 \mathrm{a}$ \\
\hline
\end{tabular}

1 Yields having 1 or more letters in common do not differ significantly.

application after planting; 3, 8 pounds Simazine applied in two 4-pound applications after planting and 3 months later.

Individual plots were 10 feet $x 15$ feet. Yams were planted at 3 feet $x$ $11 / 2$ feet in level ground, and were supported by stakes. The experiment was carried out on Humata clay described under experiment $\mathbf{A}$.

\section{RESULTS AND DISCUSSION}

\section{Experiment $A$}

Staking sharply increased yields of yams with all plant populations and planting systems (table 1). This increase in yields resulted almost exclusively from the production of much larger yams in the staked plots. Number of yams produced closely followed planting rates. Staking increased yields most when yams were planted in raised beds (treatment 4).

Yields of both staked and unstaked yams increased by about 100 hundredweight per acre when plant population was increased from 4,356 to 
7,260 plants per acre (treatment 1 vs. 2), but were not further increased by increasing population to 10,890 plants per acre.

Planting in raised beds increased yields of staked yams from 303 to 392 hundredweights per acre (treatment 2 vs. 4), but did not increase yields of unstaked yams.

The detailed data show that staking increased the percentage of misshapen yams from 18 to 35 , probably because of the larger size of the yams produced with staking. At present there is no apparent market preference based on shape of yams.

Table 3 shows how yields of yams were increased by increased population,

TABLE 3.-Cumulative effect of increasing population, staking, and planting in raised beds on yields and income from the Guinea blanco variety of yams at Orocovis

\begin{tabular}{l|c|c|c|c}
\hline \multicolumn{1}{c|}{ Practices } & $\begin{array}{c}\text { Increase } \\
\text { in yjelds } \\
\text { due to } \\
\text { practice }\end{array}$ & $\begin{array}{c}\text { Increase } \\
\text { in total } \\
\text { incomet due } \\
\text { to practice }\end{array}$ & $\begin{array}{c}\text { Estimated } \\
\text { cost of } \\
\text { practice }\end{array}$ & $\begin{array}{c}\text { Increase in } \\
\text { net income } \\
\text { due to } \\
\text { practice }\end{array}$ \\
\hline Cwut./acre & Dollars/acre & Dollars/acre & Dollars/acre \\
1, Increase from 4,356 to 7,260 plants & 106 & 530 & $98^{2}$ & 432 \\
$\begin{array}{l}\text { per acre } \\
\text { 2, (1) + Staking }\end{array}$ & 78 & 390 & $222^{8}$ & 168 \\
3, (2) + Planting in raised beds & 89 & 445 & $145^{4}$ & 300 \\
4, Total for 3 practices combined & 273 & 1,365 & 465 & 900 \\
\hline
\end{tabular}

1 Assuming price of $\$ 5.00$ per cwt.

2 Assuming a, $1 / 4$ pound of seed at $\$ 4.00$ per cwt. b, additional cost of harvesting at $50 \&$ per cwt. c, additional planting costs of $\$ 5.00$ per 1,000 seed.

Assuming a, stakes at $\$ 5.00$ per 100 lasting for 2 crops. b, staking costs of 50 per 100.

- Assuming additional cost of preparing land at $\$ 100$ per acre.

staking, and planting in beds. Yields of yams were more than tripled and estimated income above increased costs attributable to the practices increased by a total of $\$ 900$ per acre by combining these three cultural practices.

\section{Experiment $B$}

Yields of yams growing in raised beds and supported by stakes increased with each increase in population up to 10,890 plants per acre when a standard 4-foot distance was used between rows (treatments 1,2 , and 3, in table 2).

Planting approximately on the square sharply increased yields in all populations (table 2). With 10,890 plants per acre for example, yields were increased by 84 hundredweights per acre (from 453 to 537 hundredweights) 
by planting at 2 feet $\mathrm{x} 2$ feet (treatment 5 ) rather than at 4 feet $\mathrm{x} 1$ foot (treatment 3 ).

With 2-foot x 2-foot plantings, staked yams planted in raised beds in this experiment yielded over 26 tons of tubers per acre, showing the high yield potential of this major food crop of the Hot Humid Tropics when properly managed.

\section{Experiment $C$}

Simazine applied at the rate of 8 pounds per acre either in one application immediately after planting or in two 4-pound applications did not affect yields of yams. No cultivation was necessary in these plots, but the handcultivated plots had to be weeded 3 times. Yields averaged 200 hundredweights per acre.

It can be concluded that yams of the Guinea blanco variety should be planted approximately at 2 feet $\mathrm{x} 2$ feet distance in raised beds or ridges and should be supported by stakes. Simazine applied soon after planting is an excellent herbicide for yams.

\section{SUMMARY}

Staking sharply increased yields of the Guinea Blanco variety of yams mainly by increasing size of tubers.

Planting in raised beds markedly increased yields of staked yams.

Yields of yams growing in raised beds and supported by stakes increased with population up to 10,890 plants per acre with a standard 4 feet between beds. Planting approximately on the square further increased yields above those obtained with 4-foot rows. Highest yields, exceeding 26 tons of tubers per acre, were obtained with 10,890 plants per acre and 2 feet $\mathrm{x} 2$ feet plantings.

Combining closer planting, staking, and planting in beds more than tripled yields of yams.

Simazine applied at the rate of 8 pounds per acre soon after planting, gave excellent results as a herbicide for yams.

\section{RESUMEN}

El uso de estacas aumentó marcadamente la producción del ñame de la variedad Guinea Blanco, mayormente como resultado de haberse aumentado el tamaño de los tubérculos.

La producción de ñame aumentó según el número de plantas hasta llegar a 10,890 por cuerda, al sembrarse estaqueado y en bancos de 4 pies de separación. Las siembras hechas a una distancia de 2 pies $\mathrm{x} 2$ pies produjeron más que las que se hicieron a 4 pies $\times 1$ pie, con igual número de plantas por cuerda. Los más altos rendimientos (más de 26 toneladas de tubérculos) se 
obtuvieron cuando se usaron 10,890 plantas por cuerda, a una separación de 2 pies $x 2$ pies.

El aumentar el número de plantas, usar estacas y sembrar en bancos triplicó la producción de ñames.

El Simazine, aplicado a razón de 8 libras por cuerda inmediatamente después de hacer la siembra, dio excelentes resultados como un yerbicida preemergente en el cultivo del ñame.

\section{LITERATURE CITED}

1. Campbell, J. S. and Gooding, H. J., Recent developments in the production of food crops in Trinidad, Trop. Agr. 39 (4): 261, 1962.

2. Chapman, T., Some investigation into factors limiting yields of the White Liabon yam under Trinidad conditions, Trop. Agr. 42 (2): 143-51, 1965.

3. Kasasian, L., Chemical weed control in tropical root crops, Trop. Agr. 44 (2): 143-50, April 1967.

4. Kinman, C. F., Yam culture in Puerto Rico, Bull. 27, Agr. Expt. Sta., Río Piedras, P.R., 1921.

5. Vicente-Chandler, J., Caro-Costas, R., and Boneta, E., High crop yields produced with or without tillage on three typical soils of the Humid Mountain Region of Puerto Rico, J. Agr. Univ. P.R. 50 (2): 146-50, 1966.

6. Wood, C. R., Experiments with yams in Trinidad, Emp. J. Exp. Agr., 1316, 1933.

Please note that the ninth column heading, Table 1, page 244, in the paper: preharvest changes in the PHYsical and chemical properties of plantains, F. Sánchez Nieva et al., which appeared in $J$. Agr. Univ. P.R. 62 (3): 241-55, 1968, is in error.

The table boxhead now reads as follows: "Texture: Shear-press maximum-force values (lb./sq in)."

The heading should read as indicated below:

"Texture: Shear-press maximum-force values (pounds)." 